\title{
Chemical Synthesis of Copper Nanospheres and Nanocubes and Their Antibacterial Activity Against Escherichia coli and Enterococcus sp.
}

\author{
A. Alshareef ${ }^{1} \cdot$ K. Laird ${ }^{2}$ - R. B. M. Cross ${ }^{1}$
}

Received: 29 February 2016/Revised: 27 June 2016/Published online: 24 November 2016

(C) The Chinese Society for Metals and Springer-Verlag Berlin Heidelberg 2016

\begin{abstract}
The interest in synthesising inorganic nanomaterials for biological applications has increased in recent years, especially for antibacterial purposes. In the present study, spherical and cube-shaped copper nanoparticles were synthesised by a chemical reduction method and their efficacy as antimicrobial agents against both Gram-negative (Escherichia coli) and Gram-positive (Enterococcus sp.) organisms investigated. The nanoparticles were characterised using ultraviolet/ visible spectroscopy, scanning electron microscopy, energy-dispersive spectroscopy and X-ray diffraction. Copper nanocubes were found to be more antimicrobial when compared with copper nanospheres, and it is postulated that whilst both sets of nanoparticles have similar total surface areas, the different shapes have different active facets and surface energies, which may lead to differing bactericidal behaviour.
\end{abstract}

KEY WORDS: Copper nanoparticles; Scanning electron microscopy (SEM); Antibacterial; Escherichia coli; Enterococcus sp.

\section{Introduction}

The antibacterial properties of nanoparticles depend on a number of factors including the type of micro-organism and the physicochemical properties of the nanoparticles $[1,2]$. The rate of bacterial growth can also affect the tolerance of bacteria to nanoparticles: fast-growing bacteria are more sensitive to nanoparticles than slow-growing bacteria [3]. This is most likely due to the expression of stress-response genes within the bacteria themselves [4]. Copper nanoparticles (CuNPs) have been shown to have a

Available online at http://link.springer.com/journal/40195

R. B. M. Cross

rcross@dmu.ac.uk

1 Faculty of Technology, School of Engineering and Sustainable Development, Emerging Technologies Research Centre, De Montfort University, Leicester LE1 9BH, UK

2 Faculty of Health and Life Sciences, Leicester School of Pharmacy, De Montfort University, Leicester LE1 9BH, UK great deal of potential for exploitation in a variety of areas due to their antibacterial properties [5]. These include applications in the textile industry, water disinfection, medicine and food packaging [6], as well as in dentistry to avoid/combat infection [7].

Results from in vitro studies in animal models demonstrate size-dependent effects of $\mathrm{Cu}$ particles [8]. For example, nanosized $\mathrm{Cu}$ particles have been found to be more toxic than microsized $\mathrm{Cu}$ particles following oral administration to rats [8]. $\mathrm{Cu}$ ions are redox-active, meaning that the high intracellular concentration, which can result after dissolution of CuNPs inside the cell, usually results in great oxidative stress [8]. Signs of oxidative stress and genotoxicity have also been reported after cellular exposure to copper oxide nanoparticles (CuONPs) and include the generation of intercellular reactive oxygen species (ROS) and oxidative DNA lesions [9, 10]. However, nanoparticles of $\mathrm{Cu}$ and $\mathrm{CuO}$ have different mechanisms of toxicity following cell exposure. CuNPs target the cell membrane causing a rapid loss of its integrity, which then leads to cell death. Conversely, CuONPs appear 
endocytosed within cells in the first hours of interaction which is followed by DNA damage [11].

There are some reports in the literature describing the size-dependent antibacterial activity of nanoparticles of silver (AgNPs) [12]. However, there is very little published work as to how nanoparticle shape might affect the level of antibacterial behaviour. A recent study has suggested that the antibacterial effect of AgNPs may be affected by their total surface area and facet reactivity, whereby AgNPs with larger effective contact areas and more reactive facets exhibit stronger antibacterial activity [13]. In this regard, this paper describes a comparative study of the antibacterial activity of $\mathrm{Cu}$ nanospheres (CuNSs) and nanocubes (CuNCs) of the same primary dimension (the diameter of $\mathrm{CuNSs} /$ side length of CuNCs was found on average to be approximately $270 \mathrm{~nm}$ ) and the same total surface area per unit mass $\left(2.480 \mathrm{~m}^{2} / \mathrm{g}\right)$.

\section{Experimental}

\subsection{Materials}

All chemicals for this study were purchased from SigmaAldrich, UK, without further purification. They include copper sulphate $\left(\mathrm{CuSO}_{4}\right)$, ascorbic acid $\left(\mathrm{C}_{6} \mathrm{H}_{8} \mathrm{O}_{6}\right)$, polyvinylpyrrolidone (PVP) $\left(\left[\mathrm{C}_{6} \mathrm{H}_{9} \mathrm{NO}\right] n\right)$, sodium hydroxide $(\mathrm{NaOH})$ and ethylene glycol (EG) $\left(\mathrm{C}_{2} \mathrm{H}_{6} \mathrm{O}_{2}\right)$.

\subsection{Synthesis of CuNSs}

The CuNS growth solution was prepared by adding $1.59 \mathrm{~g}$ of $\mathrm{CuSO}_{4}, 1 \mathrm{~g}$ PVP and $4.36 \mathrm{~g}$ of ascorbic acid to $100 \mathrm{ml}$ of de-ionised (DI) water (Milli-Q, 18.2 M $\mathrm{cm}^{-1}$ ). PVP was used as a surfactant and ascorbic acid as a reducing agent. The solution was then stirred and maintained at $80^{\circ} \mathrm{C}$. The formation of CuNPs was confirmed once the colour of the mixture turned brick red from a blue colour. $\mathrm{CuSO}_{4}$ primarily dissociated to $\mathrm{Cu}^{2+}$ and $\mathrm{SO}_{4}{ }^{2-}$ in water, and $\mathrm{Cu}^{2+}$ ions were hydrolysed into $\mathrm{Cu}\left(\mathrm{OH}_{2}\right)$ as a precursor. Further reduction in $\mathrm{Cu}\left(\mathrm{OH}_{2}\right)$ took place in the presence of ascorbic acid to form $\mathrm{Cu}_{2} \mathrm{O}$. Lastly, $\mathrm{Cu}_{2} \mathrm{O}$ was reduced further to form CuNPs. The reaction can be represented as follows [14]:

$$
\begin{aligned}
& \mathrm{CuSO}_{4} \rightarrow \mathrm{Cu}^{2+}+\mathrm{SO}_{4}^{2-}, \\
& 2 \mathrm{H}_{2} \mathrm{O} \rightarrow 2 \mathrm{H}^{+}+2 \mathrm{OH}^{-}, \\
& \mathrm{Cu}^{2+}+2 \mathrm{OH}^{-} \rightarrow \mathrm{CuOH}_{2}, \\
& 2 \mathrm{Cu}\left(\mathrm{OH}_{2}\right)+\mathrm{C}_{6} \mathrm{H}_{8} \mathrm{O}_{6} \rightarrow \mathrm{Cu}_{2} \mathrm{O}+\mathrm{C}_{6} \mathrm{H}_{6} \mathrm{O}_{6}+3 \mathrm{H}_{2} \mathrm{O},
\end{aligned}
$$

$\mathrm{Cu}_{2} \mathrm{O}+\mathrm{C}_{6} \mathrm{H}_{8} \mathrm{O}_{6} \rightarrow \mathrm{Cu}+\mathrm{C}_{6} \mathrm{H}_{6} \mathrm{O}_{6}+\mathrm{H}_{2} \mathrm{O}$,

$2 \mathrm{H}^{+}+\mathrm{SO}_{4}^{2-} \rightarrow \mathrm{H}_{2} \mathrm{SO}_{4}$.

\subsection{Synthesis of CuNCs}

Five grams of $\mathrm{CuSO}_{4}$ and $2.5 \mathrm{~g}$ of $\mathrm{NaOH}$ were mixed with $50 \mathrm{ml}$ of EG in a three-necked round flask equipped with a condenser and stirred at room temperature before being heated to $160{ }^{\circ} \mathrm{C}$. The colour of the mixture changed from blue to deep blue, to green, to yellow, to yellowish brown and finally to brick red in $1.5 \mathrm{~h}$. The reaction can be represented as follows [15]:

$\mathrm{HOCH}_{2} \mathrm{CH}_{2} \mathrm{OH} \rightarrow \mathrm{CH}_{3} \mathrm{CHO}+\mathrm{H}_{2} \mathrm{O}$,

$4 \mathrm{NaOH}+\mathrm{CuSO}_{4} \cdot 5 \mathrm{H}_{2} \mathrm{O} \rightarrow \mathrm{Na}_{2}\left[\mathrm{Cu}(\mathrm{OH})_{4}\right]+\mathrm{Na}_{2} \mathrm{SO}_{4}+5 \mathrm{H}_{2} \mathrm{O}$

$\mathrm{Na}_{2}\left[\mathrm{Cu}(\mathrm{OH})_{4}\right]+2 \mathrm{HOCH}_{2} \mathrm{CH}_{2} \mathrm{OH} \rightarrow \mathrm{Na}_{2}\left[\mathrm{Cu}\left(\mathrm{OCH}_{2} \mathrm{CH}_{2} \mathrm{O}\right)_{2}\right]$

$+4 \mathrm{H}_{2} \mathrm{O}$

$2 \mathrm{Na}_{2}\left[\mathrm{Cu}\left(\mathrm{OCH}_{2} \mathrm{CH}_{2} \mathrm{O}\right)_{2}\right]+\mathrm{H}_{2} \mathrm{O} \rightarrow \mathrm{Cu}_{2} \mathrm{O}+\mathrm{CH}_{3} \mathrm{COCOCH}_{3}$ $+2 \mathrm{Na}_{2}\left(\mathrm{OCH}_{2} \mathrm{CH}_{2} \mathrm{O}\right)$

$\mathrm{Cu}_{2} \mathrm{O}+2 \mathrm{CH}_{3} \mathrm{CHO} \rightarrow 2 \mathrm{Cu}+\mathrm{H}_{2} \mathrm{O}$.

The synthesised nanoparticles of both shapes were centrifuged at $4600 \mathrm{r} / \mathrm{min}$ three times and washed with DI water to remove any impurities and unreacted precursors. Freeze drying was then used to transform the copper colloid to a powder phase.

\subsection{Particle Characterisation}

The CuNPs were characterised by ultraviolet/visible (UVVis) spectroscopy (Evolution 300 UV-Vis, over the wavelength range $300-1000 \mathrm{~nm})$, scanning electron microscopy (SEM), energy-dispersive X-ray (EDX) spectroscopy (LEO S430) and X-ray diffraction (XRD) (Bruker D8 Advance diffractometer). Various solutions were dropcast onto silicon and glass substrates for SEM/EDX and UV-Vis/XRD investigations, respectively.

\subsection{Antibacterial Activity Studies}

\subsubsection{Bacterial Strains and Culture Conditions}

To study the antibacterial activity of CuNPs, the Grampositive bacteria Enterococcus sp. and Gram-negative bacteria Escherichia coli (E. coli) were selected as target organisms. Both bacterial strains were stored in LuriaBertani broth at $-80{ }^{\circ} \mathrm{C}$ and then cultured in nutrient broth (NB) at $37{ }^{\circ} \mathrm{C}$ for $24 \mathrm{~h}$. 


\subsubsection{Screening of CuNPs for Antibacterial Activity}

Antibacterial activity was determined using the disc diffusion method. Initially, $20 \mathrm{ml}$ of molten nutrient agar (NA) media was poured into sterilised petri dishes. One hundred microlitres of the cultured bacteria was then dispensed, and a sterilised spreader was used to spread the bacteria on the surface of the NA. Disc diffusion papers were placed onto the NA followed by pouring $50 \mu \mathrm{l}$ of a $100 \mu \mathrm{g} / \mathrm{ml}$ solution of CuNPs onto the disc paper; everything was then incubated for $24 \mathrm{~h}$, and the zone of inhibition was measured from the edge of the disc to the edge of confluent growth.

\subsubsection{Determining the Growth Curve of E. coli and Enterococcus sp. Bacterial Cells Exposed to Different Concentration of CuNPs}

To obtain the growth kinetics curves of bacterial cells exposed to CuNPs, NB with different concentrations of CuNPs (2500, 1000,100 and $50 \mu \mathrm{g} / \mathrm{ml}$ ) was used. Two hundred microlitres of the bacteria treated with CuNPs was dispensed into a 96-well plate using a multi-microlitre pipette, and then, each well was measured for optical density (OD) at $595 \mathrm{~nm}$ using a spectrophotometer. The results were then compared to a control sample which contained no CuNPs.

\section{Results and Discussion}

The absorption spectrum of the CuNS solution (Fig. 1a) shows an intense peak at $580 \mathrm{~nm}$, which is attributable to the surface plasmon absorption of copper [16]. In Fig. 1b, CuNCs show three broad peaks observed at 335, 450 and
$785 \mathrm{~nm}$, respectively. The absorption spectra of metal nanoparticles are mediated by surface plasmon resonances (SPRs) that shift to longer wavelengths as particle size increases. The shape and position of plasmon absorption of CuNPs are mainly dependent on the dielectric medium, particle size and the surface adsorbed species. According to Mie's theory [17], only a single SPR band is expected in the absorption spectra of spherical nanoparticles, whilst anisotropic particles could increase the number of SPR bands to two or more depending on the particle shape. The number of SPR peaks rises as the symmetry of the nanoparticles decreases. SEM images of prepared CuNSs and CuNCs are shown in Fig. 2a, b, respectively. The spherically shaped nanoparticles have an average diameter of $\sim 270 \mathrm{~nm}$. Figure $2 \mathrm{~b}$ shows uniformly cube-shaped NPs with sides of length $\sim 270 \mathrm{~nm}$. EDX analysis of the CuNPs shows the presence of $\mathrm{Cu}$, silicon (from the substrate) and low levels of oxygen and carbon (Fig. 3).

XRD patterns shown in Fig. $4 a$, $b$ confirm the formation of fcc CuNPs. Diffraction peaks at $2 \theta=43.2^{\circ}$ and $74.4^{\circ}$ are attributed to (111) and (220) planes of $\mathrm{Cu}$ with a cubic phase (JCPDS card No. 04-0836). However, the XRD pattern for CuNSs shows an additional peak indexed as the (220) diffraction of $\mathrm{Cu}_{2} \mathrm{O}$ (JCPDS card No. 05-0667) that can be associated with the slow oxidation of metallic CuNPs in air to form $\mathrm{CuO}$.

Disc diffusion data indicate that both shapes inhibit the growth of Gram-positive bacteria and Gram-negative bacteria. Figure 5 illustrates that $\mathrm{CuNCs}$ are more active on both bacteria when compared with CuNSs, with zones of inhibition of 17 and $7 \mathrm{~mm}$ against E. coli and Enterococcus sp., respectively. This compares to inhibition zones of $12 \mathrm{~mm}$ against E. coli and $5 \mathrm{~mm}$ against Enterococcus sp. for CuNSs (Fig. 6).
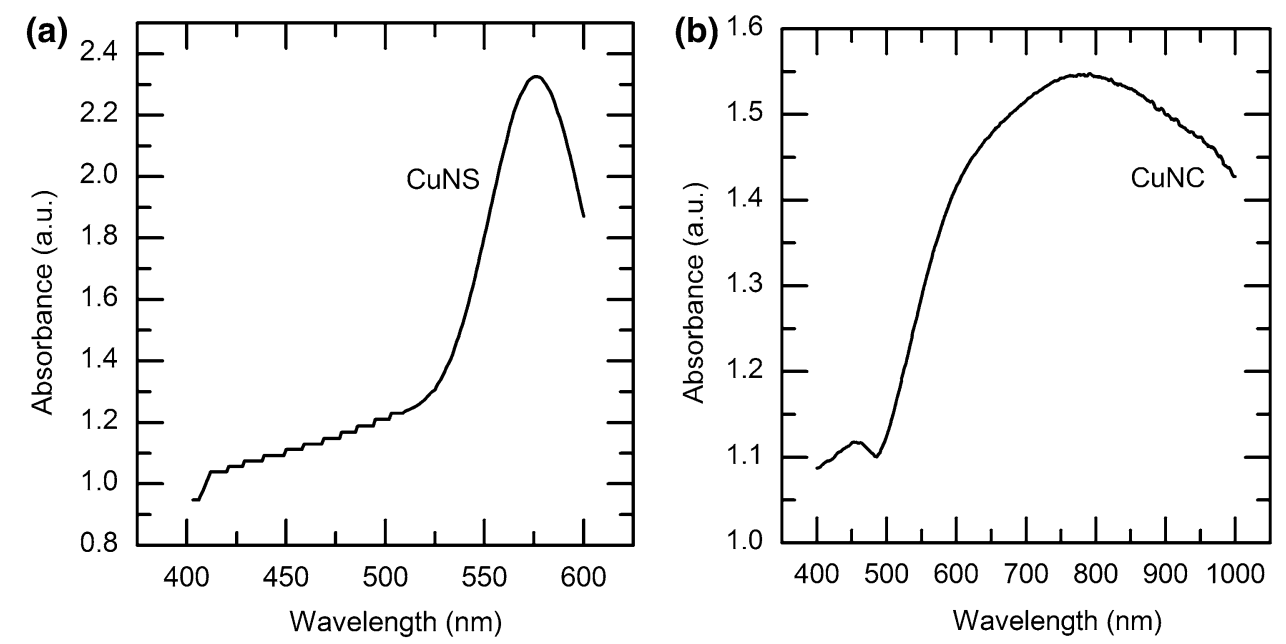

Fig. 1 UV-Vis spectra of CuNPs: a CuNSs, b CuNCs 

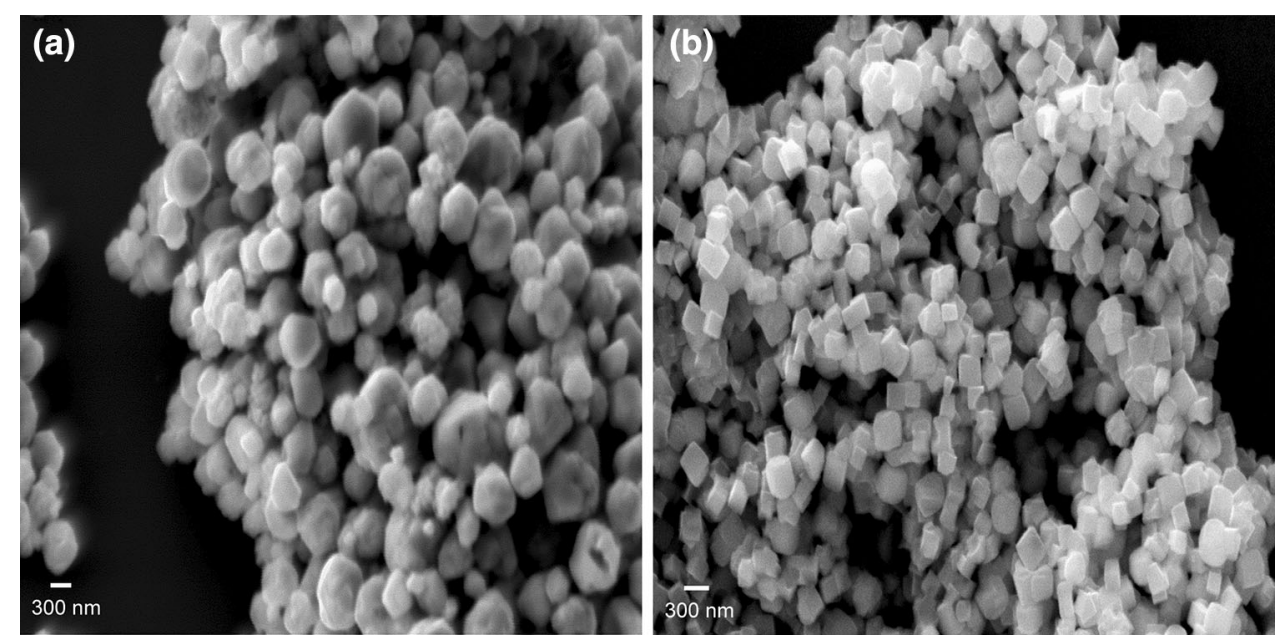

Fig. 2 SEM images of a CuNSs, b CuNCs
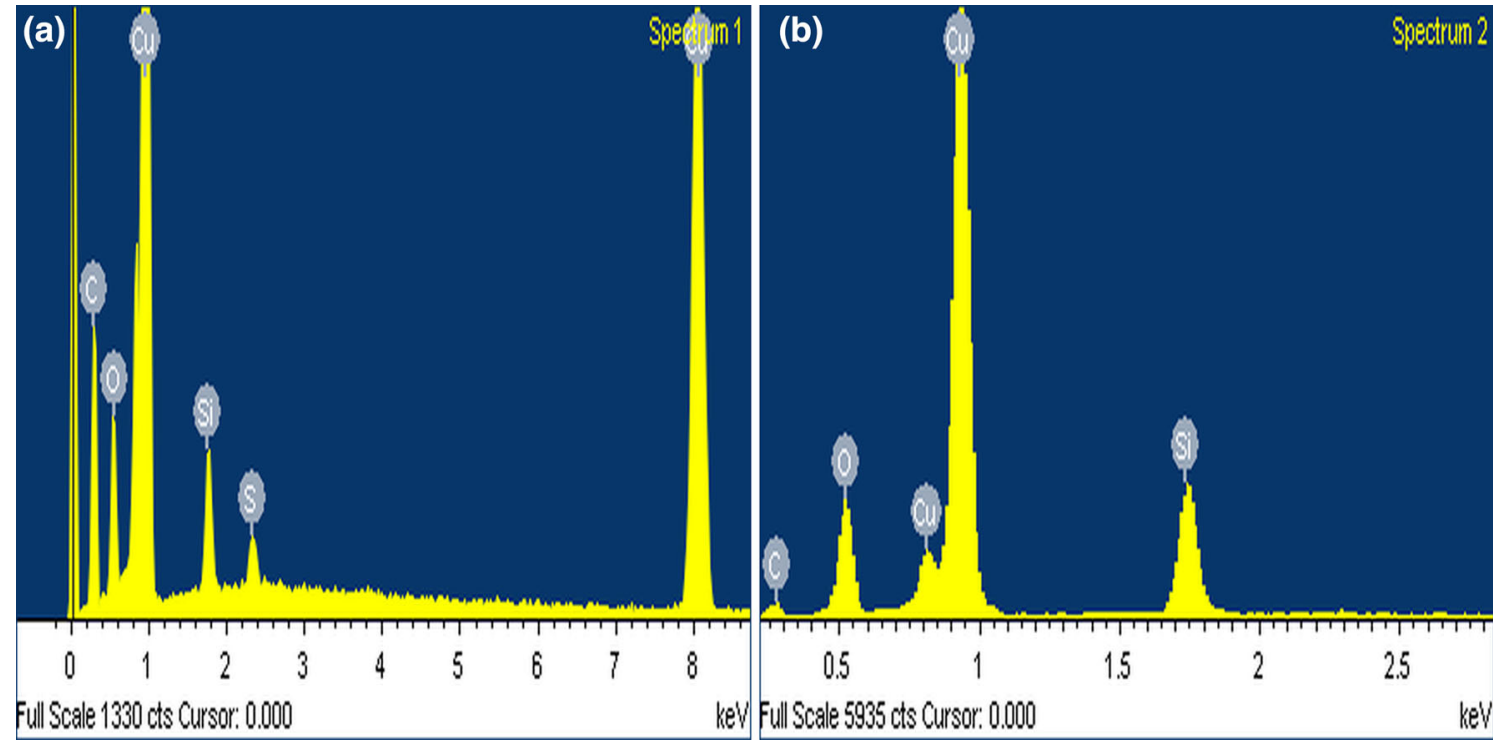

Fig. 3 EDX of a CuNSs, b CuNCs

Figure 7a, b shows the growth kinetics of E. coli and Enterococcus sp. treated with CuNSs. The growth of E. coli treated with 2500,1000, 100 and $50 \mu \mathrm{g}$ of CuNSs was inhibited after $4 \mathrm{~h}$, whilst the growth of Enterococcus sp. was inhibited after $2 \mathrm{~h}$ apart from the highest concentration, the results of which may have been affected by nanoparticle-enhanced scattering. Figure $8 \mathrm{a}$, b shows the growth curves of bacteria treated with all concentrations of CuNCs. Inhibition was again evident after $2-4 \mathrm{~h}$ for E. coli and for Enterococcus sp. after $2 \mathrm{~h}$ for the lower concentrations only, with the highest seemingly taking longer to take effect (most likely due to enhanced scattering once more).

The better inhibitory effects that were observed in E. coli compared to Enterococcus sp. for both shapes are related to the difference in the outer casing of these bacteria. A Gram-positive bacterium, such as Enterococcus sp., has a thick layer of peptidoglycan. In contrast, a Gramnegative bacterium, such as $E$. coli, has an outer membrane covering a thin layer of peptidoglycan. The positive $\mathrm{Cu}$ ions released from the NPs may be attracted to the negatively charged bacterial cell walls which may then be ruptured or compromised by the NPs in question; this can lead to protein denaturation followed by cell death [18]. For Gram-negative bacteria with a thinner outer casing, this is likely to occur more readily which would help to explain the difference in the levels of inhibition here. Moreover, there is also the possibility that the active facets of differently shaped nanoparticles could be affecting directly their antibacterial behaviour. 

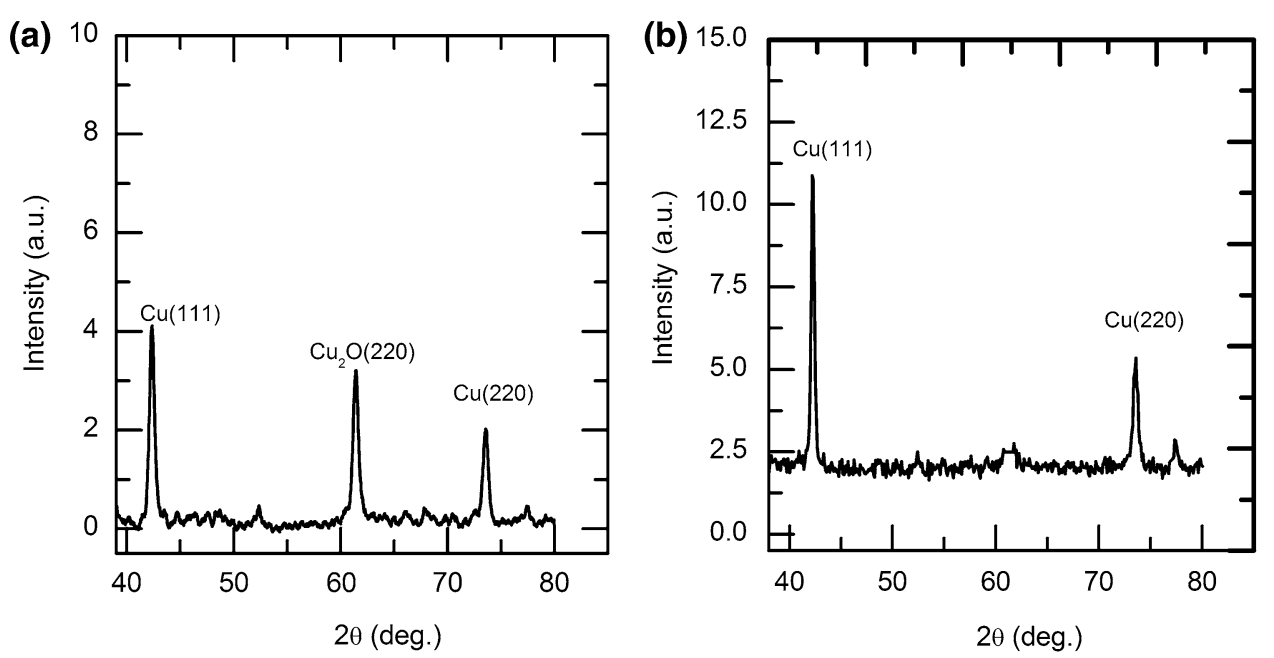

Fig. 4 XRD patterns confirming the formation of CuNPs: a CuNSs, b CuNCs

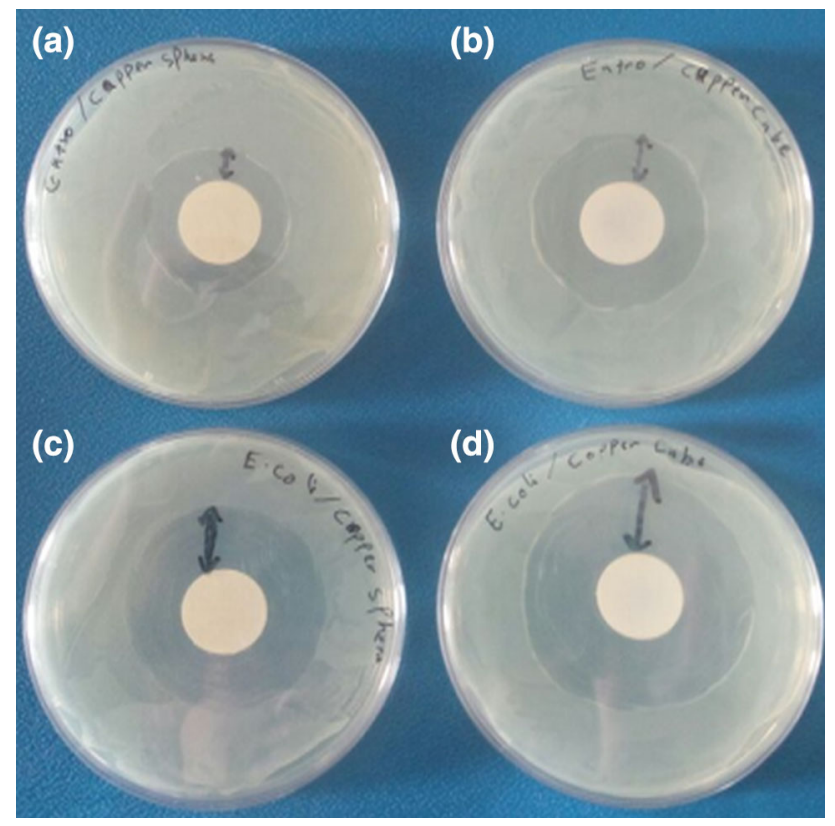

Fig. 5 Disc diffusion method showing inhibition zones against Enterococcus sp. for CuNSs a, CuNCs $\mathbf{b}$ and inhibition zones against E. coli for CuNSs c, CuNCs d

It has been argued previously that the reactivity of silver is greater when high atomic density facets are present such as the (111) plane [19]. In this regard, the XRD pattern for CuNCs in this work shows a higher intensity of (111) when compared with CuNSs. This could be expected as quasispherical particles tend to exhibit lower levels of (111)

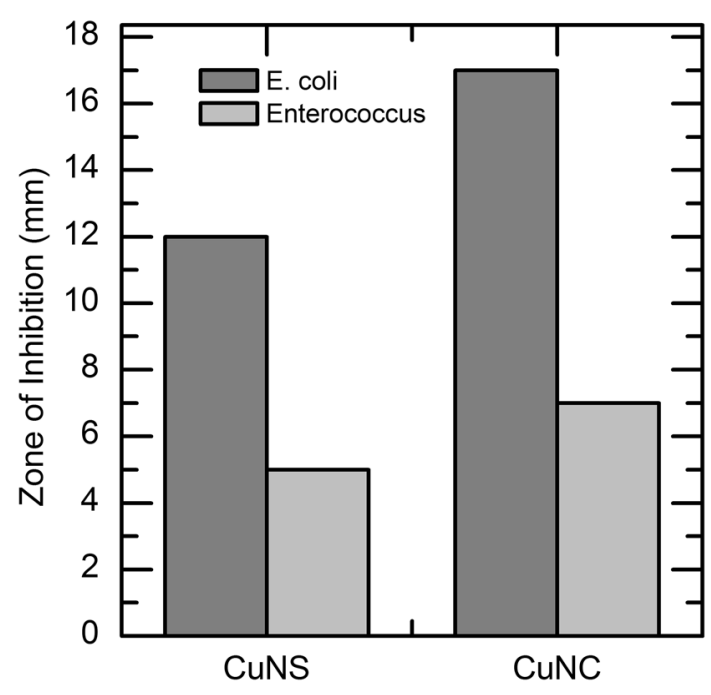

Fig. 6 Annular radii of zones of inhibition of CuNCs and CuNSs against E. coli and Enterococcus sp.

facets [20]. Hence, it is postulated that it is the higher reactivity of the CuNCs here that leads to increased antibacterial activity. The higher reactivity may result in the $\mathrm{Cu}^{+}$ion binding more readily causing damage to cellular functions by, for example, disrupting the osmotic pressure equilibrium and causing local $\mathrm{pH}$ changes. Work is ongoing to ascertain more fully the mechanisms involved and the potential for nanoparticle ingress within the cells themselves. 

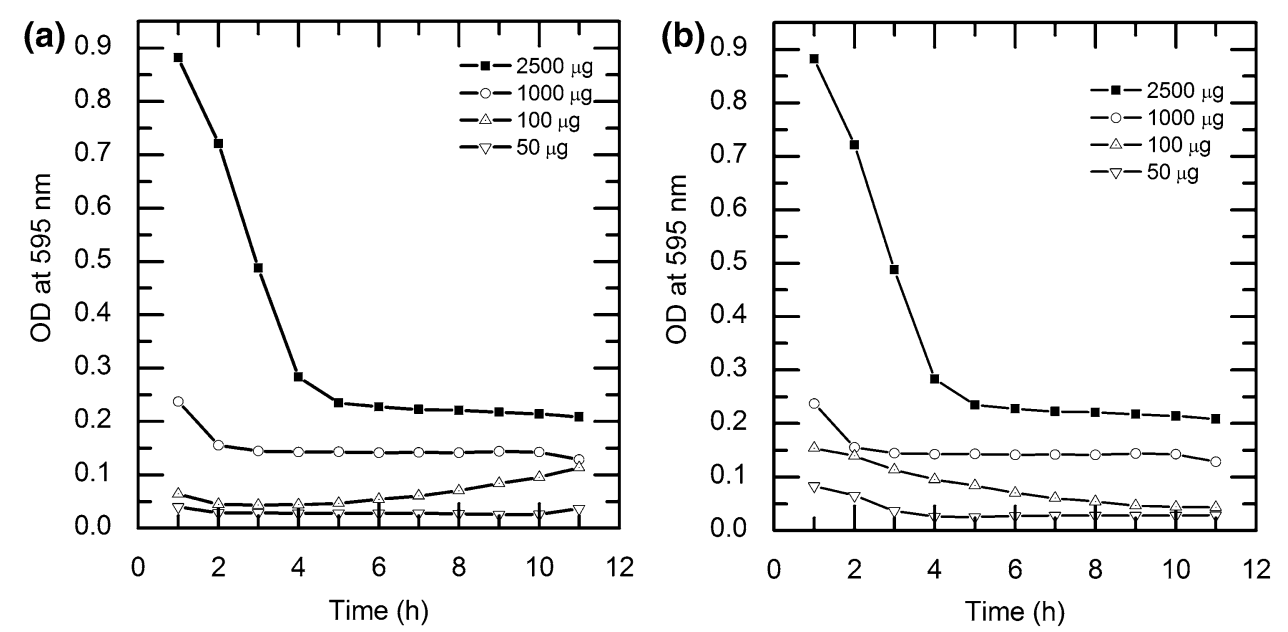

Fig. 7 a Growth curves of $E$. coli treated with different concentrations $(\mu \mathrm{g} / \mathrm{ml})$ of CuNSs; b growth curves of Enterococcus sp. treated with different concentrations of CuNSs
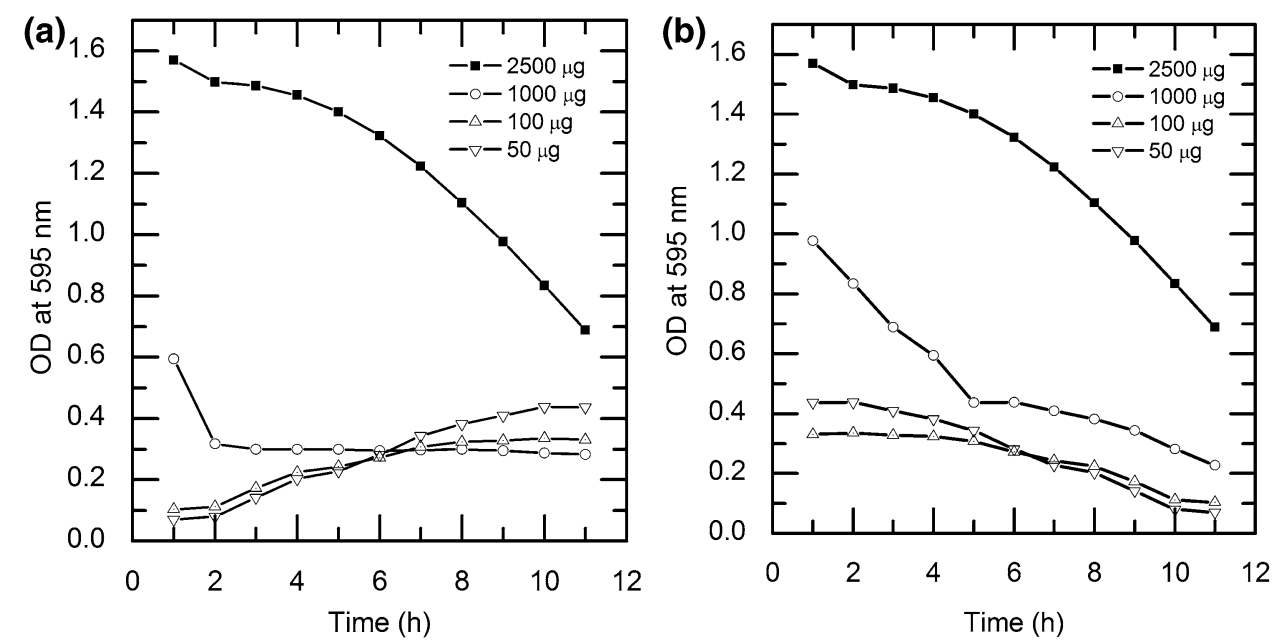

Fig. 8 a Growth curves of E. coli treated with different concentrations of $(\mu \mathrm{g} / \mathrm{ml})$ of CuNCs; $\mathbf{b}$ growth curves of Enterococcus sp. treated with different concentrations of CuNCs

\section{Conclusion}

In this study, CuNSs and CuNCs were synthesised by using a chemical reduction method in water and EG, respectively. The particles were characterised by SEM, EDX, $\mathrm{XRD}$ and UV-Vis spectroscopy. Studies of the antibacterial activity of the different CuNPs show that whilst both shapes were effective in inhibiting the growth of Grampositive bacteria and Gram-negative bacteria, CuNCs had the greatest effect. This suggests that whilst the CuNPs have similar surface areas, it is the different shapes and in particular the differing levels of surface reactivity that contribute to the demonstrated behaviour. The highly reactive (111) facet was more prevalent in the CuNCs compared with CuNSs, and this higher reactivity may be the principal cause that ultimately led to cell death more rapidly in both bacterial strains studied.

\section{References}

[1] W. Witte, Infect. Genet. Evol. 4, 187 (2004)

[2] M.R. Brown, D.G. Allison, P. Gilbert, J. Antimicrob. Chemother. 22, 777 (1988)

[3] C. Lu, M.J. Brauer, D. Botstein, Mol. Biol. Cell 20, 891 (2009)

[4] G. Ren, D. Hu, E.W. Cheng, M.A. Vargas-Reus, P. Reip, R.P. Allaker, Int. J. Antimicrob. Agents 33, 587 (2009)

[5] A. Jamshidi, M. Jahangiri, Asian J. Biol. Sci. 7, 183 (2014)

[6] R.P. Allaker, J. Dent. Res. 89, 1175 (2010)

[7] I. Subhankari, P.L. Nayak, World J. Nano Sci. Technol. 2, 10 (2013) 
[8] Z. Chen, H. Meng, G. Xing, C. Chen, Y. Zhao, G. Jia, T. Wang, H. Yuan, C. Ye, F. Zhao, Z. Chai, C. Zhu, X. Fang, B. Ma, L. Wan, Toxicol. Lett. 163, 109 (2006)

[9] M. Ahamed, M.A. Siddiqui, M.J. Akhtar, I. Ahmad, A.B. Pant, H.A. Alhadlaq, Biochem. Biophys. Res. Commun. 396, 578 (2010)

[10] N. Hanagata, F. Zhuang, S. Connolly, J. Li, N. Ogawa, M. Xu, ASC Nano 5, 9326 (2011)

[11] K. Midander, P. Cronholm, H.L. Karlsson, K. Elihn, L. Möller, C. Leygraf, I. Odnevall-Wallinder, Small 5, 389 (2009)

[12] Z. Lu, K. Rong, J. Li, H. Yang, R. Chen, J. Mater. Sci. Mater. Med. 24, 1465 (2013)
[13] X. Hong, J. Wen, X. Xiong, Y. Hu, Environ. Sci. Pollut. Res. 5, 4489 (2016)

[14] P. Gurav, S. Naik, K. Ansari, S. Srinath, K. Kishore, Colloids Surf. A 441, 589 (2014)

[15] J. Sun, Y. Jing, Y. Jia, M. Tillard, C. Belin, Mater. Lett. 59, 3933 (2005)

[16] S. Pal, Y.K. Tak, J.M. Song, Appl. Environ. Microbiol. 73, 1712 (2007)

[17] G. Mie, Ann. Phys. 25, 377 (1976)

[18] T. Theivasanthi, M. Alagar. arXiv preprint arXiv:1110.1372

[19] D.W. Hatchett, S. Henry, J. Phys. Chem. 100, 9854 (1996)

[20] B. Wiley, Y. Sun, B. Mayers, Y. Xia, Chem. Eur. J. 11, 454 (2005) 